\title{
Results of laparoscopic cholecystectomy in a third-level university hospital after 17 years of experience
}

\author{
P. Priego, C. Ramiro ${ }^{1}$, J. M. Molina ${ }^{1}$, G. Rodríguez Velasco ${ }^{1}$, E. Lobo ${ }^{1}, J$ Galindo ${ }^{1}$ and V. Fresneda \\ Department of General Surgery. Hospital General de Castellón. Spain. 'Department of General Surgery. \\ Hospital Ramón y Cajal. Madrid, Spain
}

\begin{abstract}
Objective: the aim of the study is to determine the results obtained with laparoscopic cholecystectomy at Ramón y Cajal Hospital after 17 years of experience, comparing current results with those at the beginning of the experience.

Material and methods: between 1991 and December 2007, 3,933 laparoscopic cholecystectomies were performed at the "Ramón y Cajal Hospital"; 1,849 patients were operated on between 1991 and 2000, and 2,084 between 2001 and 2007 . Patients studied included $69.8 \%$ of women and $30.2 \%$ of men, with a mean age of 56.95 years (range 9-94 years). In all, $54.68 \%$ of patients had a concomitant disease before surgery (hypertension, diabetes, ischemic heart disease, respiratory disease...). Surgery was performed by a staff surgeon for $58.04 \%$ of cases, and by a resident in the remaining $41.96 \%$. Surgical indications were cholelithiasis in $75.5 \%$, pancreatitis in $13.3 \%$, cholecystitis in $6.3 \%$, choledocholithiasis in $3.05 \%$, and others in $1.2 \%$ of cases.
\end{abstract}

Results: mean hospital stay was 3.06 days. Conversion to open surgery was required for $8.3 \%$ of cases (331 patients). The major surgical complication rate was $2.34 \%$, with the most frequent being hemoperitoneum (1\%). Common bile duct injury occurred in thirteen cases (0.3\%), 51 patients (1.3\%) were soon reoperated, and 5 patients died $(0.13 \%)$.

When the results of both decades (1991-2000 us. 2001-2007) were compared, we observed differences in the number of procedures performed by residents ( 31.7 vs. $51.1 \%, p=0.00001$ ), number of laparoscopic cholecystectomies for cholecystitis (4.9 vs. $7.53 \%, p=0.001)$, conversion rate $(5.46$ us. $11 \%, p=0.000001)$, and mean hospital stay (2.43 vs. 3.7 days, $p=0.001$ ).

Conclusion: these results should be interpreted with caution as this is a retrospective study with multiple uncontrolled variables (high number of surgeons and continuous learning curve). The lower conversion rate and mean hospital stay in the first decade of the learning curve are amazing, although this could be related to better patient selection and a lower number of cholecystites operated using a laparoscopic approach in the initial series. In general,

Received: 08-09-08

Accepted: 13-11-08.

Correspondence: Pablo Priego Jiménez. C/ Fermín Caballero, 26 1ª A. 16004 Cuenca, Spain.e-mail: papriego@hotmail.com these results are acceptable and concur with the rest of the literature.

Key words: Laparoscopic cholecystectomy. Complications. Reoperation. Conversion. Mortality. Experience.

Priego P, Ramiro C, Molina JM, Rodríguez Velasco G, Lobo E, Galindo J, Fresneda V. Results of laparoscopic cholecystectomy in a third-level university hospital after 17 years of experience. Rev Esp Enferm Dig 2009; 101: 20-30.

\section{INTRODUCTION}

Laparoscopic cholecystectomy (LC) has replaced open cholecystectomy in the treatment of patients with symptomatic gallstone disease. There is overwhelming evidence that LC offers patients less pain, shorter hospital stays, and less postoperative complications (1-4). However, although LC has shown to be a safe procedure, this technique is not devoid of risks and complications (5-7).

The aim of the study is to analyze our experience after 17 years of LC at the "Ramón y Cajal Hospital", comparing current results with those at the beginning of our experience, particularly in relation to demographic characteristics, number of interventions performed by staff surgeons versus residents, conversion to open surgery, surgical complications, re-operation, and mean hospital stay.

\section{MATERIAL AND METHODS}

Between January 1991 and December 2007, 3933 LCs were performed at the "Ramón y Cajal Hospital"; 1,849 
patients were operated between 1991 and 2000, and 2,084 between 2001 and 2007. Surgery was performed by 100 different surgeons, including residents. The patients studied included $69.8 \%$ women and $30.2 \%$ men, with a mean age of 56.95 years (range 9-94 years); $54.68 \%$ of patients had a concomitant disease before surgery (hypertension, diabetes, ischemic heart disease, respiratory disease...).

Surgery was performed by a staff surgeon in $58.04 \%$ of cases, and by a resident in $41.96 \%$. Surgical indications were cholelithiasis in $75.5 \%$, pancreatitis in $13.3 \%$, cholecystitis in $6.3 \%$, choledocholithiasis in $3.05 \%$, and others in $1.2 \%$ of cases.

\section{Evolution of cholecystectomy at the "Hospital Ramón y Cajal"}

In 1991 the first LC was performed at the Hospital Ramón y Cajal (8). During the first years of the study the procedure was only performed by 4 surgeons in the department. Gradually, all surgeons in the department, assisted by one of these four above-mentioned surgeons, were learning the laparoscopic technique. Currently our residents perform these interventions as first assistant during their first year, and perform their first LC during their second year of training. In general, residents in their fifth year, after finishing their training program, have performed $50 \mathrm{LCs}$ on average as primary surgeons, and have been assistants in around 34 additional LCs (9).

During the last 17 years, 4,813 cholecystectomies were performed in our hospital either as an open or laparoscopic approach. The number of patients operated using an open approach has decreased from 250 in 1991 to 40 in the present period $(9.5 \%)$. Simultaneously, the number of patients operated on with a laparoscopic approach has increased from 1 in 1991 to 382 nowadays (90.5\%) (Fig. 1).

The algorithm for the surgical treatment of cholelithiasis in our hospital is shown in figure 2 .

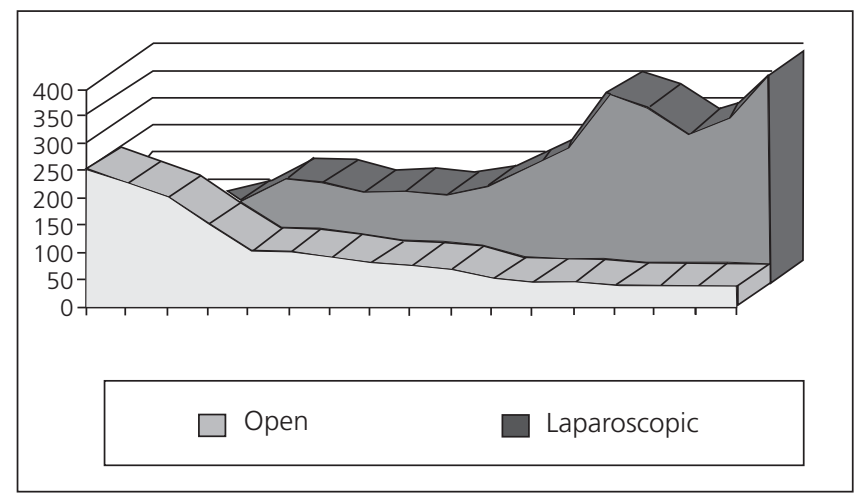

Fig. 1. Evolution of cholecystectomy at the Hospital Ramón y Cajal. Evolución histórica de la colecistectomía en el Hospital Ramón y Cajal.



Fig. 2. Therapeutic algorithm for cholelithiasis. Algoritmo de tratamiento de la colelitasis.

Basically, in patients with jaundice or in whom lithiasis was found in the bile duct by ultrasounds, an endoscopic retrograde cholangiopancreatography (ERCP) was performed. In this way, 405 ERCPs have been performed $(10.3 \%)$, basically preoperatively. However, the development of magnetic resonance cholangiography (MRC) in the last few years has decreased the number of ERCPs performed in favor of MRC.

\section{Surgical technique}

A pneumoperitoneum is created using Hasson's technique (pressure at 12-14 $\mathrm{mmHg}$ ); however, in case of significant, a Veres needle is used. At the beginning of the experience, the French technique (with the surgeon between the legs of the patient) was selected but now we prefer the American technique (with the surgeon on the left of the patient and the assistant on the right) for all cases. LC is performed as a standardized technique with 4 trocars: one infraumbilical (Hasson), a 10-mm trocar in the epigastrium, and two 5-mm trocars in the right quadrant (anterior axillary line and mid clavicular line). Cholecystectomy starts with the dissection of the posterior part of Calot's triangle. The cystic duct and artery are identified, secured with clips, and sectioned.

In the first cases an intraoperative cholangiography was routinely performed; however, this technique is now selectively performed in cases of elevated bilirubin or transaminases, history of jaundice or pancreatitis, or presence of a main bile duct longer than $12 \mathrm{~mm}$ on ultrasounds. For this reason, between the period from 2000 to 2007, 598 intraoperative cholangiographies were correctly performed (28.7\%); these were not possible in 84 cases (4\%) due to a thin cystic duct. 
The presence of a lithiasis in the main bile duct as showed by cholangiography was in most cases an indication for conversion to an open approach in order to explore the bile duct; however, in a few cases we opted for a laparoscopic exploration of the bile duct or the insertion of a transcystic tube, and then performed postoperatively an ERCP procedure.

The dissection of the gallbladder was systematically addressed with electric scissors from the infundibule to the fundus. In case of bleeding from the liver bed, hemostasis is achieved with electrocoagulation, and if necessary we can use hemostatic agents such as Surgicel ${ }^{\circledR}$. In cases of profuse bleeding we prefer to insert a tube in contact with the liver bed. The specimen is excorporated through the infraumbilical port, using a bag in cases of perforation of the gallbladder during the dissection to avoid stones within the abdominal cavity.

For the statistical evaluation of results, the SPSS (version 14.0) program was used. Categorical variables were compared using the $\chi^{2}$ test or Fisher's exact test where appropriate. A p $<0.05$ was considered statistically significant.

\section{RESULTS}

\section{Intraoperative complications}

There were 402 intraoperative complications in 3,933 patients (10.2\%). Most occurred during the dissection of Calot's triangle or the gallbladder:

- In 625 patients (16\%), the gallbladder was perforated with drain of bile and stones to the cavity. However, we have not considered this a complication as it was no cause of conversion to open surgery or immediate postoperative complications.

- The most frequent intraoperative complication was liver bed bleeding (322 patients -8.2\%) during the dissection and removal of the gallbladder. This complication never led to conversion to an open approach; however, it did result in postoperative complications including intraabdominal hematoma and abscess.

- The most important cause of bleeding was injury to the cystic artery, which occurred in 30 patients $(0.76 \%)$. In 11 cases the bleeding was managed laparoscopically, and 19 patients needed conversion to an open approach.

- Common bile duct injury (CBDI) was observed intraoperatively in 8 cases because of the use of cholangiography. The presence of bile in the peritoneum was observed in 15 additional patients, but in most was secondary to an injured duct of Luschka, and stopped with the application of clips or sutures.

- Complications related to the insertion of trocars occurred in 27 patients $(0.68 \%)$ due to bleeding from an injured epigastric artery, and were treated with either a suture around the hole of the trocar or with the insertion of a Foley's catheter inside the hole of the trocar. In 1 pa- tient an intestinal perforation occurred in relation to a Veres needle, which was sutured using an open approach. There was no lesion in major vessels.

Also, 2 important lesion of the duodenum occurred during the dissection of the triangle of Calot.

\section{Major surgical complications}

Major surgical complications developed in 92 patients $(2.34 \%)$, with hemoperitoneum, which occurred in 41 patients $(1 \%)$, being most common. Re-operation was required for 30 cases. The other 11 cases were managed in a conservative way with fluid therapy and hemotherapy.

- CBDI was found in 13 cases $(0.3 \%)$. In 8 cases the diagnosis was made intraoperatively, in 3 cases in the immediate postoperative period (stricture of CBD), and in 2 cases many months after surgery. Treatment for CBDI is shown in table I.

Table I.

\begin{tabular}{ll}
\hline \multicolumn{2}{c}{ Common bile duct injury: 13 cases (0.3\%) } \\
\hline Roux-en-Y hepatojejunostomy & 9 \\
Right hepatectomy & 2 \\
Suture ligation & 2 \\
\hline
\end{tabular}

- In 17 cases $(0.43 \%)$, a bile leak/choleperitoneum presented in the immediate postoperative period. Ten patients were treated with ERCP and papillotomy, and in seven re-operation was required.

- Intraabdominal abscesses that were treated surgically were found in 11 patients $(0.28 \%)$. In two cases, residual gallstones were found.

-Other causes of re-operation were intestinal obstruction in 6 patients $(0.15 \%)$, evisceration through the trocar in 3 cases $(0.07 \%)$, and intraabominal sepsis in 1 case $(0.02 \%)$.

In total, 51 patients were re-operated in the immediate postoperative period (1.3\%). Mortality rate was $0.13 \%$ (5 patients): intraabdominal sepsis (2 cases), pulmonary embolism, acute myocardial infarction, and choleperitoneum.

\section{Minor postoperative complications}

Other minor postoperative complications included the development of incisional hernias through the trocar's incision (cause of re-operation in 35 patients $-0.9 \%$ ), wound infection in 35 patients $(0.9 \%)$, and hemathoma of the abdominal wall in 32 cases $(0.8 \%)$.

Conversion to open surgery occurred in 331 patients $(8.3 \%)$, with the most important cause being gallbladder inflammation and inability to display anatomy safely. 
Mean hospital stay was 3.06 days (range of 0-143 days), residual choledocholithiasis rate was $2.06 \%$ (81 patients), and readmission rate was $5 \%$.

\section{Comparative analysis of results 1991-2000 vs. 2001- 2007 (Table II)}

In relation to the sex, women were predominant (72 and $68 \%$ respectively) in both decades. However, in the last decade the number of men has increased $(28 \mathrm{vs}$. $32 \%$, p: 0.0065$)$. There is no statistical significance in relation to mean age (57.2 vs. 56.7 years, p: 0.55$)$. The role of the resident in laparoscopic cholecystectomy is higher (31.7 vs. 51.05\%, p: 0.00001) in the last decade. Regarding surgical indication, there is only statistical significance for cholecystitis (4.9vs. $7.53 \%$, p: 0.0001), this being more frequent in the last decade. The rate of conversion in initial years is $5.46 \%$, and in later years is $11 \%$, which is statistically significant (p: 0.00001). Mean hospital stay was also lower in the period 19912000 than in the period 2001-2007 (2.43 vs. 3.7 days, p: 0,001). No statistical differences occurred related to major surgical complications (1.96 vs. 2.45\%, p: 0.931), re-operation (1.02 vs. $1.53 \%$, p: 0.1$)$, or mortality $(0.16$ vs. $0.0095 \%$, p: 0.89).

\section{DISCUSSION}

Laparoscopic cholecystectomy (LC) has replaced open cholecystectomy in the treatment of patients with symptomatic gallstone disease. There is overwhelming evidence that LC offers patients less pain, shorter hospitalizations, and less postoperative complications (1-4). This progressive replacement of the open approach by laparoscopy is clearly shown in our series (Fig. 1). However, as can be observed in the figure, the number of open cholecistectomies has remained stable in the last years $(9.5 \%)$. The indications for a primary open approach have been discussed above (10); although suspected gallbladder cancer and Mirizzi syndrome seem to be accepted by most surgeons, choledocholithiasis and cholecystitis are more controversial and depend on laparoscopic experience.

Table II. Comparative analysis of results $1991-2000$ vs. 2001-2007.

\begin{tabular}{|c|c|c|c|c|}
\hline & $1991-2007$ & $1991-2000$ & $2001-2007$ & $p$ value \\
\hline Number of patients & 3,933 patients & 1,849 patients & 2,084 patients & \\
\hline $\begin{array}{r}\text { Femal } \\
\text { Male }\end{array}$ & $\begin{array}{l}\text { ale: } 2,747(69.8 \%) \\
\text { le: } 1,186(30.1 \%)\end{array}$ & $\begin{array}{c}\text { Female: } 1,331(72 \%) \\
\text { Male: } 518(28 \%)\end{array}$ & $\begin{array}{c}\text { Female: 1,416 (68\%) } \\
\text { Male: } 668(32 \%)\end{array}$ & $p=0.0065$ \\
\hline 56.95 & 5 years (9-94 years) & 57.2 years ( $16-89$ years) & 56.7 years (9-94 years) & $p=0.55$ \\
\hline Concomitant disease & $2,152(54.68 \%)$ & $1,053(57 \%)$ & $1,099(54.4 \%)$ & $p=0.008$ \\
\hline $\begin{array}{l}\text { Surgeon: } \\
\text { Staff } \\
\text { Resident }\end{array}$ & $\begin{array}{l}2,283(58.04 \%) \\
1,650(41.96 \%) \\
\end{array}$ & $\begin{array}{c}1,263(68.3 \%) \\
586(31.7 \%) \\
\end{array}$ & $\begin{array}{c}1,020(48.9 \%) \\
1,064(51.05 \%)\end{array}$ & $p=0.00001$ \\
\hline $\begin{array}{l}\text { Surgical indication: } \\
\text { Cholelithiasis } \\
\text { Cholecystitis } \\
\text { Choledocholithiasis } \\
\text { Pancreatitis } \\
\text { Others } \\
\end{array}$ & $\begin{array}{c}2,971(75.54 \%) \\
248(6.3 \%) \\
120(3.05 \%) \\
523(13.3 \%) \\
47(1.2 \%)\end{array}$ & $\begin{array}{c}1,499(81 \%) \\
91(4.9 \%) \\
65(3.5 \%) \\
183(9.9 \%) \\
11(0.6 \%)\end{array}$ & $\begin{array}{c}1,472(70.6 \%) \\
157(7.53 \%) \\
55(2.64 \%) \\
340(16.3 \%) \\
36(1.72 \%)\end{array}$ & $p=0.0001$ \\
\hline Conversion & $331(8.3 \%)$ & $101(5.46 \%)$ & $230(11 \%)$ & $p=0.00001$ \\
\hline $\begin{array}{l}\text { Major surgical complications: } \\
\text { Haemoperitoneum } \\
\text { Biliar leak/coleperitoneum } \\
\text { Intestinal obstruction } \\
\text { Intraabdominal abscess } \\
\text { CBDI } \\
\text { Intestinal perforation } \\
\text { Evisceration } \\
\text { Medical complications } \\
\text { Residual choledocolithiasis }\end{array}$ & $\begin{array}{c}92(2.34 \%) \\
41(1 \%) \\
17(0.43 \%) \\
6(0.15 \%) \\
11(0.28 \%) \\
13(0.3 \%) \\
3(0.007 \%) \\
1(0.02 \%) \\
47(1.2 \%) \\
81(2.06 \%)\end{array}$ & $\begin{array}{c}41(1.96 \%) \\
18(0.97 \%) \\
6(0.32 \%) \\
3(0.16 \%) \\
7(0.38 \%) \\
7(0.37 \%) \\
0(0 \%) \\
0(0 \%) \\
18(0.97 \%) \\
23(1.24 \%)\end{array}$ & $\begin{array}{c}51(2.45 \%) \\
23(1.1 \%) \\
11(0.52 \%) \\
3(0.14 \%) \\
4(0.2 \%) \\
6(0.28 \%) \\
1(0.047 \%) \\
3(0.14 \%) \\
29(1.4 \%) \\
58(2.78 \%)\end{array}$ & $p=0.931$ \\
\hline Early re-operation & $51(1.3 \%)$ & $19(1.02 \%)$ & $32(1.53 \%)$ & $p=0.1$ \\
\hline Mortality & $5(0.13 \%)$ & $3(0.16 \%)$ & $2(0.0095 \%)$ & $p=0.89$ \\
\hline Mean hospital stay & 3.06 days & 2.43 days & 3.7 days (medium 2 days) & $p=0.001$ \\
\hline
\end{tabular}


The decreased number of open cholecistectomies has represented a smaller training opportunity for residents during their education. The problem starts when a laparoscopic procedure fails and conversion to an open approach becomes necessary, or in those difficult cases in which a primary open approach is indicated, as these are the cases where residents start their training in open cholecystectomy. For this reason, in spite of the fact that laparoscopic cholecystectomy is the gold standard for gallbladder disease, we should not forget training our residents in the open approach.

The results of our series should be interpreted with caution as this is a retrospective study with multiple uncontrolled variables. One of them is the high number of surgeons (more than 100, including residents) that participate in the study, and other variable is the learning curve (extending along the study), as it is every year that some junior surgeons learn the technique. However, it is important to remark that in spite of these reasons, neither major surgical complications nor the rate of re-operation or mortality have significantly changed during the study. The reason is that we have learned to avoid complications even if we perform more difficult operations as compared to the beginning.

The rate of major surgical complications in our series is $2.34 \%$, similar to other authors in the literature (11-15). One of the most feared complications during laparoscopic cholecistectomy remains CBDI.

The incidence of CBDI in the literature is around 0.2$1 \%$ (16-20). In our series, the rate of CBDI was $0.3 \%$ (13 cases). We identified intraoperatively 8 cases $(61.5 \%)$, here being very important the use of intraoperative cholangiography. Of these 8 cases we observed a complete section of the common bile duct in six cases that required a Roux-en-Y hepatojejunostomy. In two cases a lateral wall injury of the major biliary tree was observed and repaired with suture. In 3 cases the injury was detected in the immediate postoperative period: one lesion was healed by the electrocoagulation, and the other by clipping the CBD and right hepatic duct. These two cases presented with important intraoperative bleeding, and the lesion resulted from the application of many clips to stop bleeding without clearly seeing the vessel. In the last 2 cases the injury was identified many months after surgery: one of them presented with jaundice, and the other with a right hepatic abscess secondary to a stricture in the right hepatic duct; both of them required reoperation (right hepatectomy).

The selective or systematic use of intraoperative cholangiography has been discussed for many years (21-24). In our experience, although we have decreased the number of intraoperative cholangiographies, and perform these procedures in selected cases $(28.7 \%)$, we have not seen high residual choledocholithiasis rates $(2.06 \%)$. However, we think this laparoscopic skill must be taught and learned by residents during their training program.
In general, the rate of conversion described in literature is around $2-15 \%$ (25-31). In our series the rate acquired during these 17 years is around $8.3 \%$. This rate is higher than that in other series in the literature, but we think that all university hospitals with continuous training in laparoscopic surgery have to assume a higher conversion (but not complication) rate versus other series by other authors. In our series (32) the factors associated with conversion from laparoscopic cholecistectomy included surgeon surgical experience (learning curve), older age, male sex, presence of concomitant disease (hypertension, diabetes, ischemic heart disease, chronic bronchitis,...), performance of cholecistectomy by a staff surgeon, and cholecystitis.

A comparative analysis of both decades shows a higher participation of residents in LC (31.7vs. 51.05\%) and a rising of $\mathrm{LC}$ for acute cholecystitis (4.9vs. 7.53\%) in the present decade. However, in most cases we have used conservative management for cholecystitis using antibiotics and surgery in the second line.

The lower conversion rate and shorter postoperative stay in the initial period versus the second period are interesting. The reasons that can justify this could be a better selection of easy cases to be managed laparoscopically in the beginning of the learning curve. A second reason could be that initial procedures were performed by a reduced number of surgeons. In the third place, in the first period there were fewer cholecystitis operations, which is one of the most important causes of conversion.

Finally, we would like to remark that although our results are acceptable and similar to other series in the literature, they should be interpreted with caution given that this is a retrospective study with multiple uncontrolled variables.

\section{REFERENCES}

1. Paredes JP, Carrillo A, Ramírez JA. La colecistectomía laparoscópica en España: estudio multicéntrico de 2432 enfermos. Rev Esp Enferm Dig 1994; 85: 19-26.

2. Bueno J, Planells M, Bertomeu A, Sanahuja A, Oviedo M, García Espinosa R, et al. Colecistectomía laparoscópica ambulatoria. ¿El nuevo "gold standard" de la colecistectomía? Rev Esp Enferm Dig 2006; 98: 14-24

3. Flores M, Obispo A, Docobo F, Romero E, Legupín D, Valera Z. Experiencia en el tratamiento laparoscópico de la colelitiasis del cirrótico. Rev Esp Enferm Dig 2005; 97: 648-53.

4. Feliú X, Férnandez E, Clavería R, et al. Evolución de la colecistectomía laparoscópica en los hospitales comarcales de Cataluña. Rev Esp Enferm Dig 2000; 92: 211-6.

5. Shea JA, Healey MJ, Berlin JA, Clarke JR, Malet PF, Staroscik RN, et al. Mortality and complications associated with laparoscopic cholecystectomy: A meta-analysis. Ann Surg 1996; 224: 609-704.

6. Bueno J, Serralta A, Planells M, et al. Colecistectomía laparoscópica y sus complicaciones: nuestra experiencia en nueve años. Cir Esp 2001; 69: 467-72.

7. Lobo E, Peromingo R, Galindo J, Fresneda V, et al. Complicaciones de la colecistectomía laparoscópica en un hospital docente. Secla Endosurgery; 2002. Disponible en: www.seclaendasurgery.com/seclan1/art46.htm

8. Fresneda V, Fernández Cebrian JM, Capela I, et al. Análisis de los dos primeros años (1991-1993) de un protocolo de colecistectomía 
laparoscópica en 400 pacientes. Cir Esp 1994; 56: 202-7.

9. Priego P, Lobo E, Rodríguez Velasco G, et al. ¿Es adecuada la formación del residente en cirugía laparoscópica? Rev Chilena de Cirugía 2008; 60: 418-23.

10. Visser BC, Parks RW, Garden OJ. Open cholecystectomy in the laparoscopic era. Am J Surg 2008; 195: 108-14.

11. Ludwig K, Kockerling F, Hohenberger W, Lorenz D. Surgical therapy in cholecysto/choledocholithiasis. Results of a Germany-wide questionnaire sent to 859 clinics with 123090 cases of cholecystectomy. Chirurg 2001; 72: 1171-8.

12. Ihász M, Hung CM, Regöly-Mérei J, Fazekas T, Bátorfi J, Bálint A, et al. Complications of laparoscopic cholecystectomy in Hungary: a multicentre study of 13833 patients. Eur J Surg 1997; 163: 267-74.

13. Vecchio R, Macfayden BV, Latteri S. Laparoscopic cholecystectomy: an analysis on 114005 cases of United States series. Int Surg 1998; 83: 215-9.

14. Duca S, Bala O, Al-Hajjar N, Lancu C, Puia I, Munteanu D, et al. Laparoscopic cholecystectomy: incidents and complications. A retrospective analysis of 9542 consecutive laparoscopic operations. HPB (Oxford) 2003; 5(3): 152-8.

15. Paredes JP, Puñal JA, Beiras A, et al. 1000 colecistectomías laparoscópicas: indicaciones y resultados. Cir Esp 2001; 70: 195-9.

16. Waage A, Nilsson M. Iatrogenic bile duct injury: a population-based study of 152776 cholecystectomies in the Swedish inpatient registry. Arch Surg 2006; 141: 1207-13.

17. Regoly-Mérei J, Ihász M, Szeberin Z, Sándor J, Maté M. Biliary tract complications in laparoscopic cholecystectomy. A multicenter study of 148 biliary tract injuries in 26440 operations. Surg Endosc 1998; 12: $294-300$

18. Richardson MC, Bell G, Fullarton GM. Incidence and nature of bile duct injuries following laparoscopic cholecystectomy: an audit of 5913 cases. West of Scotland Laparoscopic Cholecystectomy Audit Group. Br J Surg 1996; 83: 1356-60.

19. Archer SB, Brown DW, Smith CD, Branum GD, Hunter JG. Bile duct injury during laparoscopic cholecystectomy: results of a national survey. Ann Surg 2001; 234: 549-58.

20. Karvonen J, Gullichsen R, Laine S, Salminen P, Grönroos JM. Bile duct injuries during laparoscopic cholecystectomy: primary and long-term results from a single institution. Surg Endosc 2007; 21: $1069-73$
21. Mirza DF, Narsinmhan KL, Ferraz Neto BH, Mayer AD, McMaster $\mathrm{P}$, Buckels JA. Bile duct injury following laparoscopic cholecystectomy: referral pattern and management. Br J Surg 1997; 84: 786-90.

22. Manson JM. Intraoperative cholangiography and bile duct injury in laparoscopic cholecystectomy. Surg Endosc 2000; 14: 94-5.

23. Fletcher DR, Hobbs MST, Tan P,Valinsky LJ, Hockey RL, Pikora TJ, et al. Complications of cholecystectomy: risks of the laparoscopic approach and protective effects of operative cholangiography. A population-based study. Ann Surg 1999; 229: 449-57.

24. Pérez FJ, De Luna R, Moreno J, et al. Colecistectomía laparoscópica en pacientes mayores de 70 años: nuestra experiencia en 176 casos. Rev Esp Enferm Dig 2006; 98: 46-8.

25. Giger UF, Michel JM, Opitz I. Risk factors for perioperative complications in patients undergoing laparoscopic cholecystectomy: analysis of 22953 consecutive cases from the Swiss Association of Laparoscopic and Thoracoscopic Surgery database. J Am Coll Surg 2006; 203: 723-8

26. Bingener-Casey J, Richards ML, Stroedel WE, Schwesinger WH, Sirinek KR. Reasons for conversion from laparoscopic to open cholecystectomy: a 10-year review. J Gastrointest Surg 2002; 6(6): 8005.

27. Ibrahim S, Hean TK, Ho LS, Ravintharan T, Chye TN, Chee CH. Risk factors for conversion to open surgery in patients undergoing laparoscopic cholecystectomy. World J Surg 2006; 30: 1698-704

28. Rosen M, Brody F, Ponsky J. Predictive factors for conversion of laparoscopic cholecystectomy. Am J Surg 2002; 184: 254- 8.

29. Kama NA, Doganay M, Dolapci M, Reis E,Atli M, Kologlu M. Risk factors resulting in conversión of laparoscopic cholecystectomy to open surgery. Surg Endosc 2001; 15: 965-8.

30. Fried GM, Barkun JS, Sigman HH, et al. Factors determining conversion to laparotomy in patients undergoing laparoscopic cholecystectomy. Am J Surg 1994; 167: 35-41.

31. Alponat A, Kun CK, Koh BC, Rajnakova A, Goh PM. Predictive factors for conversion of laparoscopic cholecystectomy. World J Surg 1997; 21: 629-33.

32. Priego P, Ramiro C, Molina JM, Rodríguez Velasco G, Pina JD, Lobo E, et al. Factores asociados a la conversión en la colecistectomía laparoscópica. Secla Endosurgery; 2008. Disponible en: www.seclaendosurgery.com/seclan25/articulos/art03.htm

\title{
Resultados de la colecistectomía laparoscópica en un hospital universitario de tercer nivel tras 17 años de experiencia
}

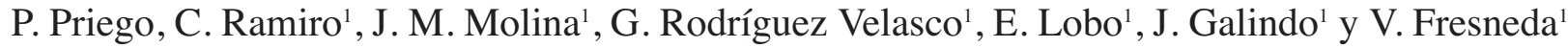 \\ Servicio de Cirugía General y Digestivo. Hospital General de Castellón. 'Servicio de Cirugía General y Digestivo. \\ Hospital Ramón y Cajal. Madrid
}

\section{RESUMEN}

Objetivo: el objetivo del estudio es conocer los resultados obtenidos con la colecistectomía laparoscópica en el Hospital Ramón y Cajal en sus 17 años de experiencia, comparando los resultados actuales con los del inicio de la experiencia.

Material y métodos: entre enero de 1991 y diciembre de 2007 se efectuaron en el Hospital Ramón y Cajal un total de 3.933 colecistectomías laparoscópicas. Fueron intervenidos 1.849 pacientes entre $1991-2000$ y 2.084 entre 2001-2007. Un
$69,8 \%$ eran mujeres y un 30,2\% varones con una edad media de 56,95 años (rango 9-94 años). Un 54,68\% de pacientes presentaban antecedentes personales de forma previa a la intervención (hipertensión, diabetes, cardiopatía isquémica, bronquitis...). La cirugía fue efectuada por un personal del staff en el 58,04\% de los casos y por un residente de cirugía en el 41,96\%. Las indicaciones quirúrgicas fueron colelitiasis 75,5\%, pancreatitis 13,3\%, colecistitis $6,3 \%$, coledocolitiasis $3,05 \%$ y otros $1,2 \%$.

Resultados: la estancia media postoperatoria fue de 3,06 días. La tasa de conversión a cirugía abierta de 8,3\% (331 pacien- 